\title{
How Has the Adoption of Business Intelligence Impacted Performance of Higher Education Institutions: Empirical Evidence from Malaysia
}

Shahrizal Nazri, Yulita Hanum P Iskandar

To Link this Article: http://dx.doi.org/10.6007/IJARBSS/v11-i1/8449

DOI:10.6007/IJARBSS/v11-i1/8449

Received: 18 November 2020, Revised: 09 December 2020, Accepted: 11 January 2021

Published Online: 29 January 2021

In-Text Citation: (Nazri \& Iskandar, 2021)

To Cite this Article: Nazri, S., \& Iskandar, Y. H. P. (2021). How Has the Adoption of Business Intelligence Impacted Performance of Higher Education Institutions: Empirical Evidence from Malaysia. International Journal of Academic Research in Business and Social Sciences, 11(1), 723-740.

\section{Copyright: (c) 2021 The Author(s)}

Published by Human Resource Management Academic Research Society (www.hrmars.com)

This article is published under the Creative Commons Attribution (CC BY 4.0) license. Anyone may reproduce, distribute, translate and create derivative works of this article (for both commercial and non-commercial purposes), subject to full attribution to the original publication and authors. The full terms of this license may be seen at: http://creativecommons.org/licences/by/4.0/legalcode

Vol. 11, No. 1, 2021, Pg. 723 - 740 


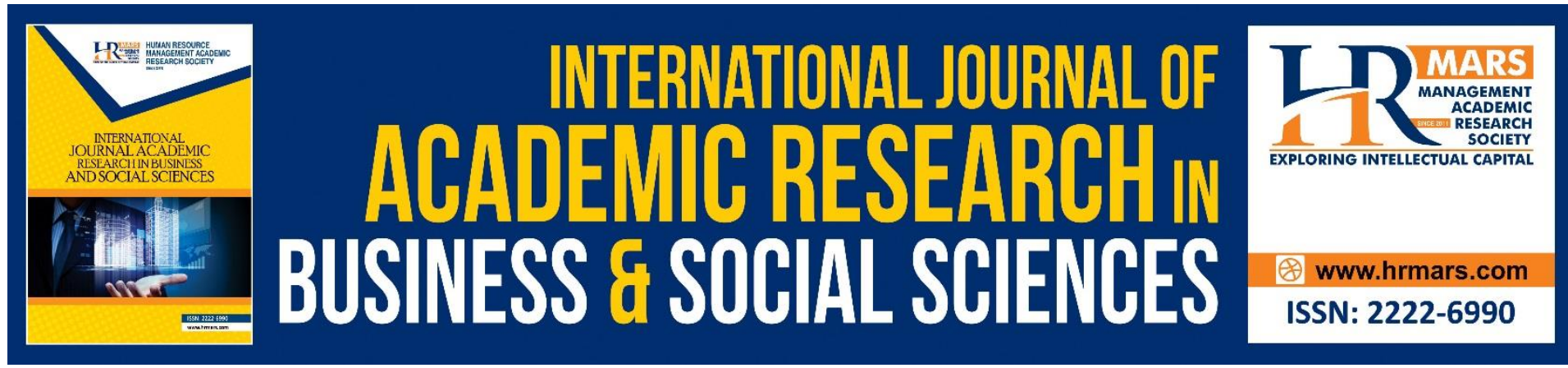

\title{
How Has the Adoption of Business Intelligence Impacted Performance of Higher Education Institutions: Empirical Evidence from Malaysia
}

\author{
1,2Shahrizal Nazri, ${ }^{1}$ Yulita Hanum P Iskandar \\ ${ }^{1}$ Graduate School of Business, Universiti Sains Malaysia, 11800 USM, Malaysia \\ ${ }^{2}$ SCentre of Knowledge, Communications \& Technology, Universiti Sains Malaysia, \\ 11800 USM, Malaysia \\ Email: yulita@usm.my
}

\begin{abstract}
Higher Education Institutions (HEIs) are lagging behind in the adoption of Business Intelligence (BI). Although the level of Business Intelligence (BI) adoption is high in large organizations, the level of $\mathrm{Bl}$ adoption in Higher Education Institutions (HEIs) is still low. There were limited studies that look at the impact of $\mathrm{Bl}$ adoption in developing countries. This study examines how BI adoption impacts the performance of HEls in Malaysia. This study applies resource-based theory to explore the relationship between $\mathrm{BI}$ adoption and performance. Data was collected through a web-form survey of 162 HEls in Malaysia listed in the Malaysia Qualification Agency (MQA). Partial least square (PLS) structural equation modelling was used to analyse the data. The results showed that there is a significant impact on the performance of HEls depending on their level of $\mathrm{BI}$ adoption. These research finding will hopefully help to encourage $\mathrm{BI}$ adoption among HEls in Malaysia.
\end{abstract}

Keywords: Business Intelligence, Higher Education, Performance, Malaysia, Technology Adoption.

\section{Introduction}

Business Intelligence (BI) has embraced the massive quantity of information collected, combined, accessed, and analysed by many organizations in their activities (Olszak, 2016).A recent survey from Gartner (2019) shows that $\mathrm{BI}$ is ranked as a top differentiating technology for their organizations and is considered as the most strategic technology area. Dresner Advisory Service (2018) reported that the top four BI objectives: (1) making better decisions; (2) improving operational efficiency; (3) growing revenues; and (4) increased competitive advantage. $\mathrm{BI}$ objectives include enhanced customer service and higher degrees of compliance and improved risk management.

$\mathrm{BI}$ is usually thought of just as tools used only by for-profit and large corporations. However, Higher Education Institutions (HEIs) are underrated candidates that are ignored in pursuing greater BI adoption. According to Dresner Advisory Service (2018), higher education has shown the low penetration of $\mathrm{BI}$ adoption as compared to other 
industries, whereas the insurance industry leads the field in $\mathrm{Bl}$ adoption, followed by the technology industry, with 40 per cent of technology organizations having adoption rates of 41 per cent or higher.

PricewaterhouseCoopers (2017) reported that many HEls are looking at adopting technological practices used by business corporations to address emerging challenges such as business sustainability. $\mathrm{BI}$ is an increasingly vital tool for the higher education environment and has made great inroads thus far (DELL, 2013). BI adoption can enable HEls to develop plans for improvement and take action to improve efficiency in their operations (EDUCASE, 2017).

As the higher education system in Malaysia grows, HEls are becoming more regulated to guarantee a higher quality of education. In Malaysia, the national quality assurance and accreditation body for education is the Malaysia Qualification Agency (MQA), which was established to ensure greater oversight of HEls, especially regarding quality and performances.

There are several reasons to show the importance and relevance of this study on $\mathrm{BI}$ adoption and its adoption in Malaysian HEls.

First, BI adoption is increasingly popular among Malaysian organizations. For example, Gartner forecasted revenue for BI projects in Malaysia to reach RM114.5 million (USD37 million) in 2013, an improvement of 9 per cent from 2012. This is as opposed to global revenue projections at USD13.8 billion, a 7 per cent increase (Gartner, 2013). Gartner again estimated Malaysia would continue as the second-largest business intelligence market in ASEAN after Singapore, reaching USD30.4 million by the year 2017, while the market for $\mathrm{BI}$ in the Asia Pacific is expected 7.4 per cent growth to reach almost USD1.4 billion in revenue in the year 2014 and more than USD1.6 billion by the year 2017 (Gartner, 2017). Thus, the possibility of BI is certainly vivid within the context of Malaysia and hence, the significance of the $\mathrm{BI}$ adoption research in the HEI setting.

Second, the higher education sector has undergone several rounds of reforms to further improve the quality of education provided (Malaysian Ministry of Education, 2015). These reforms have led to the flow of international students to HEls in Malaysia. Available statistics indicated in the year 2015, a total of 74,748 international students from over 150 nations registered to study in Malaysian HEls. 26,405 of those international students are in public HEls while the remaining 48,343 are in private HEls. Given the rise in international student enrolment in Malaysian HEls from a variety of backgrounds, the adoption of $\mathrm{BI}$ remains critical in the efficient management of student data and other HEl operations.

Graduate Tracer Study by the Ministry of Education Malaysia (MoE) (2015) indicated that about sixty per cent of those unemployed are below age 24. Every year, one out of five fresh graduates fail to secure employment six months after graduation. To put that number in context, Malaysia produces more than 250,000 graduates in a year. Among these fresh graduates, about 26 per cent of first-degree holders are unemployed. 52 per cent of these unemployed graduates are from arts and social science study backgrounds. Most unemployed fresh graduates come from Public Universities (50 per cent) and 47 per cent from Private Universities (Ministry of Education Malaysia, 2015).

Therefore, HEls need to rely strongly on the information of the student making a critical and strategic choice (Wong et al., 2018). HEls collected and tracked more student information than ever before, from student entry to student departures such as application data, course registration information, attendance information, online 
learning information, performance information, extracurricular information, internship, and employability information (Ong, 2016). The dominant group of HEls generally covers five enterprise areas: (1) student affairs; (2) academic staff affairs; (3) finance matters; (4) research and development affairs; and (5) infrastructure and development affairs (Rahmat, Ahmad, \& Ta'a, 2016). Each business area needs to be integrated and make use of application systems to help with daily tasks. The data from each application will generate useful information that can be accessed by multiple departments such as HEI senior management, faculty members, administrative staff, scientists, and other relevant parties. Administration HEls is complicated and generate volumes of data across departmental while striving for academic excellence.

There is a diversity of explanations to explain the relatively low $\mathrm{BI}$ adoption rate among $\mathrm{HEl}$ in developing countries. In the context of $\mathrm{BI}$ adoption in developing countries, many researchers claimed that the level of $\mathrm{BI}$ adoption in Malaysia is lagging when compared to the other such as Singapore, the Philippines, and Thailand (Boonsiritomachai et al., 2016; Hatta, Miskon, \& Abdullah, 2017). The typical reasons for relatively low BI adoption include technical complexity issues, the inflexibility of the software tools, lack of senior management focus and difficulty in accessing benefits provided to the organization. Thus, this study intends to investigate how $\mathrm{BI}$ adoption impacts organizational performance of HEls in Malaysia

\section{Theoretical Foundation: Resource-Based Theory (RBT)}

According to Bhanu and Magiswary (2010), RBT resource concepts and taxonomies are still tricky for researchers due to unclear concepts of organizational resources. The effect of technology adoption on organizational performance remains a topic of discussion, although many researchers have claimed that IT adoption can drive organizational performance and enable organizations to achieve a competitive advantage (Bhanu \& Magiswary, 2010). Organizations could reflect themselves as an extensive set of assets, which are the main drivers of organizational performance. Barney (1991) indicated that to attain competitive advantage, organizations need to position themselves strategically based on their value, rare, inimitable, and non-substitute resources, rather than goods and services obtained from those assets. Mahoney and Pandian (1992) studied organizational performance based on RBT and found that there are differences between organizations within the same industry as well as within the narrower boundaries of groups within industries.

\section{Organizational Performance}

Wieder and Ossimitz (2015) argued that when it comes to BI adoption, a strong sense of purpose and strategy, strong implementation, and support of BI has a positive effect on data quality, information quality, and the scope of BI. The positive effect in combination with other factors translates to a positive effect on the quality of the decision-making process. In specific, Bl adoption can play a pivotal role in the decision-making process by collecting high-value data and information. This scenario makes sense because when organizations manage their $\mathrm{BI}$ use with a clear strategy of why, how, and where the $\mathrm{BI}$ will be implemented and maintained. Then, $\mathrm{BI}$ will be able to collect high-quality information that is relevant, transparent, and trustworthy.

Rezaie, Ansarinejad, Haeri, and Nazari-Shirkouhi (2011) asserted that BI reduced time used and increased the efficiency of the decision-making method by enabling $\mathrm{BI}$ to 
analyse obtain information and knowledge from vast amounts of data. The benefit of $\mathrm{BI}$ is coherent with Wieder and Ossimitz's (2015) argument. These high-quality data and information have a beneficial impact on the performance of the decision-making system if the user has access to large amounts of data and has the authority to manage it through an insightful and purposeful use of BI.

Organizational performance, according to Gavrea, Ilies, and Stegerean (2011), has been identified as one of the most vital factors in management studies. Georgopoulos and Tannenbaum (1957) defined organizational performance as the level to which organizations perceived as a social system achieved their goals and assessed results depending on the job, individuals, and organizational structure. In the early 1960s and 1970s, it was defined as the ability of an organization to leverage its workplace for the recovery and use of restricted resources (Seashore \& Yuchtman, 1967). In the 1980s and 1990s, organizational performance was understood as an organization using a minimum of resources (efficiency) to achieve its goals (effectiveness). The concept of performance resulted in profits becoming one of the many performance indices (Boonsiritomachai et al., 2016; Gavrea et al., 2011). However, Lebas and Euske (2007) have recently outlined a set of definitions to explain the concept of organizational performance. The first definition involves performance evaluated as a collection of financial and non-financial factors that comprise of data on the number of goals and outcomes achieved.

This study hypothesizes that BI Adoption has a significant positive relationship with organizational performance.

\section{Methodology}

\section{Sample}

The HEls listed by the Malaysian Ministry of Education are the selected population for this research. There are $769 \mathrm{HEls}$ in Malaysia according to the Malaysia Qualification Agency (MQA). This number is obtained when looking at the total number of public and private universities, polytechnic, private college universities, private colleges, and public community colleges in Malaysia. Table 1 shows the type and numbers of HEls in Malaysia as accredited by Malaysia Qualification Agency (MQA). The respondent for this study is either the Chief Information Officer (CIO), IT Director, or IT Manager, who is actively participating in IT Management.

Table 1: Number of registered public and private higher education institutions in Malaysia

\begin{tabular}{|l|l|l|}
\hline TYPE OF HEI & PUBLIC HEIS & PRIVATE HEIS \\
\hline PUBLIC UNIVERSITIES & 37 & \\
\hline PRIVATE UNIVERSITIES & & 80 \\
\hline POLYTECHNICS & 33 & \\
\hline PRIVATE UNIVERSITY COLLEGES & & 40 \\
\hline COMMUNITY COLLEGES & 181 & \\
\hline PRIVATE COLLEGES & & 398 \\
\hline TOTAL & 251 & 518 \\
\hline Total of public and private higher education institutions in Malaysia $=769$ \\
\hline
\end{tabular}




\section{Data Collection}

An email was sent out to 769 participants via email, a link to the questionnaire was attached. The questionnaire was done with an online data collection approach (Google Form). Respondents are able to immediately access the online data collection form (Google Form) when they clink on the attached link.

The researcher initiated multiple follow-up attempts (i.e., sending out an email invitation to participate in the study to the direct respondents' email address) to maximize the responses. Significant challenges were faced as respondents did not respond or were unwilling to participate. This is despite the fact that some respondents were agreeable when contacted by the researcher via calls of WhatsApp messaging. Hence, even though 769 emails were initially sent out, only a total of 162 responses had been received at the end of the data collection period (January - June 2019). The response rate was 21.06 per cent from the online data collection approach, as shown below in Table 2.

Table 2: Response Rate of Distributed Questionnaires

\begin{tabular}{|l|l|}
\hline ITEMS & N \\
\hline ONLINE QUESTIONNAIRES DISTRIBUTED & 769 \\
\hline ONLINE RESPONSES RECEIVED & 162 \\
\hline NON-RESPONSES ONLINE QUESTIONNAIRES & 602 \\
\hline RESPONSE RATE & $21.06 \%$ \\
\hline
\end{tabular}

\section{Measures of Construct}

The questionnaire had four sections with a total of 25 items: screening questions, $\mathrm{BI}$ adoption, organizational performance, and demographic variables.

The purpose of the screening is to achieve the required feedback as closely as possible. As the study focuses on investigating $\mathrm{BI}$ adoption among HEls in Malaysia and the unit of analysis of this study is at the organizational level, a qualifying question was placed at the beginning of the questionnaire to be answered by potential respondents. This screening is to ensure that only those who are actively participating in the $\mathrm{BI}$ adoption process in their HEI participated in the study. The qualifying question asked was, "Do you involve in business intelligence adoption in your institutions? Yes/No. Only those people who answer yes to the qualifying question can proceed with answering the rest of the questionnaire.

The dependent variable in the research model is $\mathrm{BI}$ adoption. It is a categorical variable comprising of five stages, which are: operate, consolidate, integrate, optimize, and innovate. The constructs and measures for classifying these levels of $\mathrm{Bl}$ adoption information use in organizations are adapted from the (Davis, Miller, \& Russell, 2006; Sacu \& Spruit, 2010). As the model in this study categorizes organizations into five levels of $\mathrm{BI}$ adoption based on the five dimensions of infrastructure, knowledge process, human capital, culture, and application. The questionnaire was designed to pose five questions that represent those five dimensions.

The researcher used thirteen items to measure organization performance. These measures were taken and then customized for the researcher's study from Owusu (2017) to measure organizational performance constructs by using a 5-point Likert scale ranging from 1 (strongly disagree) to 5 (strongly agree). 


\section{Data Analysis}

Data collected were processed and analysed using a form of the structural equation model (SEM). SEM is a second-generation multivariate data analysis technique that analyses and explains a research structure with multiple variables (Hair et al., 2017). Theory testing and causal modelling is not complete without SEM especially in terms of applied multivariate analysis.

\section{Results}

\section{Demographic Profile of Responding HEls}

Table 3 illustrates the demographic profile of the HEls which participated in this survey. The majority of the HEls are from private colleges (27.8 per cent), followed by private universities (24.7 per cent). Regarding geographical location, most HEls are in Selangor (25.9 per cent) and Kuala Lumpur (13.0 per cent).

Table 3: Demographic Profile of Responding HEls

\begin{tabular}{|c|c|c|c|}
\hline \multicolumn{2}{|l|}{ DEMOGRAPHIC VARIABLE } & FREQUENCY & $\begin{array}{l}\text { PeRCENTAGE } \\
\text { (\%) }\end{array}$ \\
\hline \multirow{6}{*}{ CATEGORY OF HEI } & PUBLIC UNIVERSITY & 21 & 13.0 \\
\hline & POLYTECHNIC & 23 & 14.2 \\
\hline & Public College & 14 & 8.6 \\
\hline & PRIVATE UNIVERSITY & 40 & 24.7 \\
\hline & PRIVATE UNIVERSITY COLLEGE & 19 & 11.7 \\
\hline & Private College & 45 & 27.8 \\
\hline \multirow{14}{*}{$\begin{array}{l}\text { THE STATE OF HEI } \\
\text { LOCATED }\end{array}$} & JOHOR & 11 & 6.8 \\
\hline & KEDAH & 7 & 4.3 \\
\hline & KELANTAN & 4 & 2.5 \\
\hline & MELAKA & 5 & 3.1 \\
\hline & NeGERI SEMBILAN & 12 & 7.4 \\
\hline & PAHANG & 12 & 7.4 \\
\hline & PERAK & 10 & 6.2 \\
\hline & PERLIS & 5 & 3.1 \\
\hline & PULAU PINANG & 10 & 6.2 \\
\hline & SABAH & 6 & 3.7 \\
\hline & SARAWAK & 6 & 3.7 \\
\hline & SELANGOR & 42 & 25.9 \\
\hline & TERENGGANU & 11 & 6.8 \\
\hline & $\begin{array}{l}\text { Wilayah PersekUtuan } \\
\text { LUMPUR }\end{array}$ & 21 & 13.0 \\
\hline
\end{tabular}

\section{BI Adoption among HEl in Malaysia}

BI Adoption among HEls as described by 162 respondents is summarized in Table 4 . The results are from the first part of the questionnaire. This section is comprised of five questions representing each dimension of the $\mathrm{BI}$ maturity model. Five choices were provided for each level of $\mathrm{BI}$ Adoption. The respondents were then asked to respond with the $\mathrm{BI}$ applications used by their institutions and its characteristics. This allows to researcher to understand $\mathrm{BI}$ adoption as understood and interpreted by their 
institutions. The results here in turn allows categorization of the level of adoption in their HEls.

Table 4: Business Intelligence Adoption among HEls.

\begin{tabular}{|c|c|c|c|c|c|c|c|c|c|c|}
\hline & \multicolumn{2}{|c|}{ INFRASTRUCTURE } & \multicolumn{2}{|c|}{$\begin{array}{l}\text { KNOWLEDGE } \\
\text { PROCESS }\end{array}$} & \multicolumn{2}{|c|}{$\begin{array}{l}\text { HUMAN } \\
\text { CAPITAL }\end{array}$} & \multicolumn{2}{|c|}{ Culture } & \multicolumn{2}{|c|}{ APPLICATION } \\
\hline & $\mathrm{N}$ & $\%$ & $\mathrm{~N}$ & $\%$ & $\mathrm{~N}$ & $\%$ & $\mathrm{~N}$ & $\%$ & $\mathrm{~N}$ & $\%$ \\
\hline Operate & 46 & 28.4 & 48 & 29.6 & 28 & 17.3 & 20 & 12.3 & 37 & 22.8 \\
\hline CONSOLIDATE & 64 & 39.5 & 42 & 25.9 & 67 & 41.4 & 68 & 42.0 & 60 & 37.0 \\
\hline INTEGRATE & 32 & 19.8 & 40 & 24.7 & 57 & 35.2 & 41 & 25.3 & 41 & 25.3 \\
\hline OptIMIZE & 15 & 9.3 & 32 & 19.8 & 10 & 6.2 & 33 & 20.4 & 8 & 4.9 \\
\hline INNOVATE & 5 & 3.1 & 0 & 0.0 & 0 & 0.0 & 0 & 0.0 & 16 & 9.9 \\
\hline
\end{tabular}

Based on Table 4, for the infrastructure dimension, more than one-third of the respondents indicated that their institutions were at consolidate stage. More than a quarter indicated that their organizations were at the operate stage, followed by 19.8 per cent at the integrate stage. Only 9.3 per cent of respondents indicated that their organization's infrastructure was at the optimizing stage, with only a few respondents (3.1 per cent) selecting the innovate stage.

From the knowledge process dimension, nearly one-third of the respondents indicated that the knowledge process of their organizations was at the operate stage followed by 25.9 per cent at the consolidate stage and 24.7 per cent at the integrate stage. Only 19.8 per cent of respondents indicated that their organization's knowledge process was at the optimize stage and none at the innovate stage.

From the human capital dimension, a majority of the respondents ( 41.4 per cent) indicated that their organizations' human capital was at the consolidate stage, followed by 35.2 per cent at the integrate stage, 17.3 per cent at operate stage, 6.2 per cent at the optimize stage and none at the innovate stage.

From the culture dimension, a majority of the respondents ( 42.0 per cent) indicated that their organizations' culture were at the consolidate stage, followed by 25.3 per cent at the integrate stage, 20.4 per cent at the optimize stage, 12.3 per cent at the operate stage and none at the innovate stage.

Last but not least, from the application dimension, a majority of the respondents (37.0 per cent) indicated that their organizations' application were at the consolidate stage, followed by 25.3 per cent at the integrate stage, 22.8 per cent at the operate stage, 4.9 per cent at the optimize stage and 9.9 per cent at the innovate stage. 
Table 5: Level of Business Intelligence Adoption among HEls

\begin{tabular}{|l|l|l|}
\hline LeVEL OF BI AdOPTION & FREQUENCY & PER CENT \\
\hline OPERATE & 10 & 6.17 \\
\hline CONSOLIDATE & 60 & 37.04 \\
\hline INTEGRATE & 61 & 37.65 \\
\hline OPTIMIZE & 31 & 19.14 \\
\hline TOTAL & 162 & 100.00 \\
\hline
\end{tabular}

From Table 5, a majority of the HEls (37.65 per cent) indicated that their institution's level of $\mathrm{Bl}$ adoption was at the integrate stage, followed by 37.04 per cent at the consolidate stage, 19.14 per cent at the optimize stage, 6.17 per cent at the operate stage and none at the innovate stage.

The BI Adoption among HEls described by the 162 respondents is summarized in Error! Reference source not found. . A majority of the HEIs (37.65 per cent) indicated that their institution's level of BI adoption at the integrate stage, followed by 37.04 per cent at the consolidate stage, 19.14 per cent at the optimize stage, 6.17 per cent at the operate stage and none at the innovate stage.

After categorizing the level of $\mathrm{BI}$ adoption in participating HEls into four stages, each stage was profiled based on descriptive statistics in terms of frequencies and percentages. The result allowed a more detailed description of characteristics in the $\mathrm{BI}$ adoption of each stage. The comparison is only made between different levels of $\mathrm{BI}$ adoption.

Table 6: Level of Business Intelligence Adoption among HEls.

\begin{tabular}{|l|l|l|}
\hline LEVEL OF BI ADOPTION & FREQUENCY & PER CENT \\
\hline OPERATE & 10 & 6.17 \\
\hline CONSOLIDATE & 60 & 37.04 \\
\hline INTEGRATE & 61 & 37.65 \\
\hline OPTIMIZE & 31 & 19.14 \\
\hline TOTAL & 162 & 100.00 \\
\hline
\end{tabular}

From the Table 6, a majority of the HEls (37.65 per cent) indicated that their institution's level of $\mathrm{BI}$ adoption was at the integrate stage, followed by 37.04 per cent at the consolidate stage, 19.14 per cent at the optimize stage, 6.17 per cent at the operate stage and none at the innovate stage.

After categorizing the level of $\mathrm{BI}$ adoption in participating HEls into four stages, each stage was profiled based on descriptive statistics in terms of frequencies and percentages. The result allowed a more detailed description of characteristics in the $\mathrm{BI}$ adoption of each stage. The comparison is only made between different levels of $\mathrm{BI}$ adoption. Table 7 showed the descriptive statistics of responding HEls across the level of $\mathrm{Bl}$ adoption among HEls. 
Table 7: Descriptive Statistics of Responding HEls Across the Level of Business Intelligence Adoption among HEls.

\begin{tabular}{|c|c|c|c|c|c|c|c|c|c|c|}
\hline \multirow{3}{*}{$\begin{array}{l}\text { CATEGORY } \\
\text { OF HEI }\end{array}$} & \multicolumn{8}{|c|}{ LEVEL OF BI ADOPTION } & \multirow{2}{*}{\multicolumn{2}{|c|}{ TOTAL }} \\
\hline & \multicolumn{2}{|c|}{ OpERATE } & \multicolumn{2}{|c|}{ CONSOLIDATE } & \multicolumn{2}{|c|}{ INTEGRATE } & \multicolumn{2}{|c|}{ OPTIMIZE } & & \\
\hline & $\begin{array}{l}N=1 \\
0\end{array}$ & $\%$ & $\begin{array}{l}N=6 \\
0\end{array}$ & $\%$ & $\begin{array}{l}N=6 \\
1\end{array}$ & $\%$ & $\begin{array}{l}N=3 \\
1\end{array}$ & $\%$ & $\mathbf{N}$ & $\%$ \\
\hline $\begin{array}{l}\text { PUBLIC } \\
\text { UNIVERSITY }\end{array}$ & 2 & $9.5 \%$ & 6 & $\begin{array}{l}28.6 \\
\%\end{array}$ & 10 & $\begin{array}{l}47.6 \\
\%\end{array}$ & 3 & $\begin{array}{l}14.3 \\
\%\end{array}$ & 21 & $\begin{array}{l}100.0 \\
\%\end{array}$ \\
\hline $\begin{array}{l}\text { POLYTECHNI } \\
\text { C }\end{array}$ & 2 & $8.7 \%$ & 14 & $\begin{array}{l}60.9 \\
\%\end{array}$ & 4 & $\begin{array}{l}17.4 \\
\%\end{array}$ & 3 & $\begin{array}{l}13.0 \\
\%\end{array}$ & 23 & $\begin{array}{l}100.0 \\
\%\end{array}$ \\
\hline $\begin{array}{l}\text { Public } \\
\text { College }\end{array}$ & 0 & $0.0 \%$ & 5 & $\begin{array}{l}35.7 \\
\%\end{array}$ & 7 & $\begin{array}{l}50.0 \\
\%\end{array}$ & 2 & $\begin{array}{l}14.3 \\
\%\end{array}$ & 14 & $\begin{array}{l}100.0 \\
\%\end{array}$ \\
\hline $\begin{array}{l}\text { PRIVATE } \\
\text { UNIVERSITY }\end{array}$ & 2 & $5.0 \%$ & 8 & $\begin{array}{l}20.0 \\
\% \\
\end{array}$ & 12 & $\begin{array}{l}30.0 \\
\% \\
\end{array}$ & 18 & $\begin{array}{l}45.0 \\
\% \\
\end{array}$ & 40 & $\begin{array}{l}100.0 \\
\% \\
\end{array}$ \\
\hline $\begin{array}{l}\text { PRIVATE } \\
\text { UNIVERSITY } \\
\text { COLLEGE }\end{array}$ & 2 & $\begin{array}{l}10.5 \\
\%\end{array}$ & 11 & $\begin{array}{l}57.9 \\
\%\end{array}$ & 5 & $\begin{array}{l}26.3 \\
\%\end{array}$ & 1 & $5.3 \%$ & 19 & $\begin{array}{l}100.0 \\
\%\end{array}$ \\
\hline $\begin{array}{l}\text { Private } \\
\text { College }\end{array}$ & 2 & $4.4 \%$ & 16 & $\begin{array}{l}35.6 \\
\%\end{array}$ & 23 & $\begin{array}{l}51.1 \\
\%\end{array}$ & 4 & $8.9 \%$ & 45 & $\begin{array}{l}100.0 \\
\%\end{array}$ \\
\hline TOTAL & 10 & $6.2 \%$ & 60 & $\begin{array}{l}37.0 \\
\%\end{array}$ & 61 & $\begin{array}{l}37.7 \\
\%\end{array}$ & 31 & $\begin{array}{l}19.1 \\
\%\end{array}$ & $\begin{array}{l}16 \\
2\end{array}$ & $\begin{array}{l}100.0 \\
\%\end{array}$ \\
\hline
\end{tabular}

\section{Measurement Model Assessment}

From Table 8, it can be observed that the all two $Q^{2}$ values for $B I$ Adoption $\left(Q^{2}=0.331\right)$ and Organizational Performance $\left(Q^{2}=0.048\right)$ were more than 0 , indicating that the research model had adequate predictive relevance.

BI Adoption explained that 9.5 per cent of the variance in organizational performance. The $R^{2}$ value of 0.627 was above the 0.26 value as suggested by Cohen (1988), which indicated a substantial model. Furthermore, the $R^{2}$ value of 0.109 was above 0.10 , as suggested by Falk and Miller (1992) that recommended that the $R^{2}$ value should be equal or greater than 0.10 for the variance explained of an endogenous construct to be deemed adequate. Therefore, the $\mathrm{R}^{2}$ for the research model constructs was comparable to recent findings in the literature (Hair et al., 2017).

The validity and reliability of the measurement items were analysed to ensure accuracy. This can be done by looking at factors such as the individual loadings, internal composite reliability, and discriminant validity. Two types of validity tests can be performed to assess the validity of the reflective measurement model: the convergent validity test or the discriminant validity test.

The researcher assessed the convergent validity and discriminant validity. First, the reflective measurement model is evaluated for convergent validity. The evaluation is based on indicator loadings, composite reliability (CR), and average variance extracted (AVE) (Hair et al., 2017). The results are presented in Table 8. 
INTERNATIONAL JOURNAL OF ACADEMIC RESEARCH IN BUSINESS AND SOCIAL SCIENCES

Vol. 11, No. 1, 2021, E-ISSN: 2222-6990 @ 2021 HRMARS

Table 8: Measurement Model

\begin{tabular}{|c|c|c|c|c|c|c|}
\hline CONSTRUCTS & ITEMS & LOADING & AVEA & CR & $Q^{2}$ & $\mathbf{R}^{2}$ \\
\hline \multirow{3}{*}{ BI ADOPTION } & 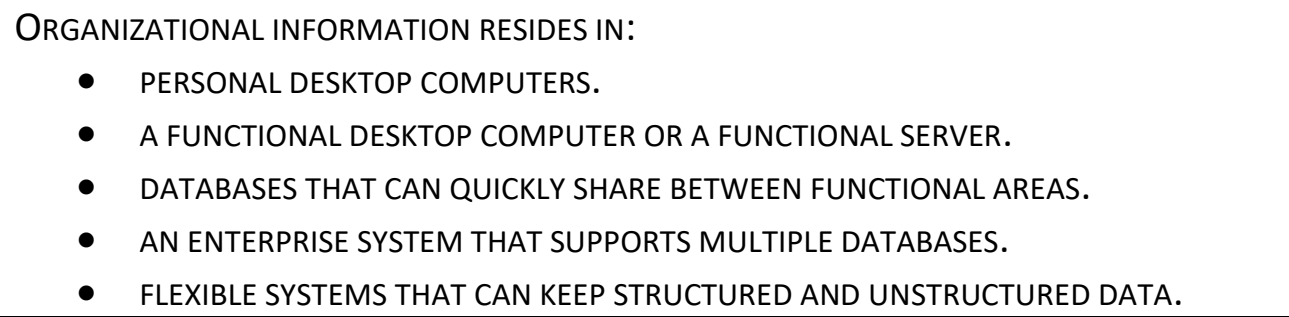 & 0.784 & 0.609 & 0.857 & \multirow{3}{*}{0.040} & \multirow{3}{*}{0.095} \\
\hline & $\begin{array}{l}\text { KNOWLEDGE PROCESS IN INSTITUTIONS CAN BE DESCRIBED AS: } \\
\text { - INDIVIDUAL STAFFS DEVELOP THEIR PROCESSES TO MANAGE DATA. } \\
\text { - STAFFS IN THE SAME FUNCTIONAL AREA SHARE THE SAME PROCESSES IN MANAGING } \\
\text { DATA. } \\
\text { - ALL FUNCTIONAL AREAS IN THE ENTERPRISE USE THE SAME PROCESSES TO MANAGE } \\
\text { DATA. } \\
\text { - THE PROCESSES FOR MANAGING DATA ARE STANDARDIZED AND IN LINE WITH } \\
\text { OUTSIDE ENTERPRISES. } \\
\text { - NOT ONLY STANDARDIZED PROCESSES BUT ALSO ENTERPRISE PLANS AIM TO } \\
\text { ESTABLISH NEW PROCESSES TO SUPPORT FORTHCOMING INNOVATIONS. }\end{array}$ & 0.898 & & & & \\
\hline & $\begin{array}{l}\text { MOST STAFF MEMBERS: } \\
\text { - LACK OF COMPUTER SKILLS AND OFTEN MAKE DECISIONS BASED ON THEIR } \\
\text { - } \text { EXPERIENCE. } \\
\text { RELY ON SOME OTHER STAFF WITH COMPUTER SKILLS TO MANAGE AND ANALYSES } \\
\text { - } \text { COULD USE COMPUTER SOFTWARE FOR MANAGING AND ANALYZING DATA. } \\
\text { - } \text { COULD USE ADVANCED DECISION-MAKING SOFTWARE. } \\
\text { - HAVE EXPERTISE IN USING THE ADVANCED DECISION-MAKING SOFTWARE. }\end{array}$ & 0.523 & & & & \\
\hline
\end{tabular}


INTERNATIONAL JOURNAL OF ACADEMIC RESEARCH IN BUSINESS AND SOCIAL SCIENCES

Vol. 11, No. 1, 2021, E-ISSN: 2222-6990 @ 2021 HRMARS

\begin{tabular}{|c|c|c|c|c|c|c|}
\hline CONSTRUCTS & ITEMS & LOADING & AVEA & CR & $\mathbf{Q}^{2}$ & $\mathbf{R}^{2}$ \\
\hline & $\begin{array}{l}\text { ORGANIZATIONAL CULTURE TOWARD CHANGE CAN BE VIEWED AS: } \\
\text { - CHANGE IS FEAR AMONG STAFF. } \\
\text { - STAFF WILL ACCEPT CHANGE IF IT LEADS TO BENEFITS FOR THEM OR THEIR GROUP. } \\
\text { - STAFF IS USING TO CHANGING AND ACCEPTING CHANGE WHEN IT IS UNDERSTOOD. } \\
\text { - STAFFS VIEW CHANGE AS AN OPPORTUNITY RATHER THAN A THREAT. } \\
\text { PREVIOUS CHANGES TO THE BUSINESS PROCESS THAT HAVE FAILED, BUT THAT LEAD } \\
\text { TO LEARNING, ARE ACCEPTED WITHOUT REBUKE OR PUNISHMENT. }\end{array}$ & 0.861 & & & & \\
\hline \multirow{9}{*}{$\begin{array}{l}\text { ORGANIZATIONAL } \\
\text { PERFORMANCE }\end{array}$} & $\begin{array}{l}\text { THERE HAD BEEN AN ENHANCEMENT OF EMPLOYEES' WORK SATISFACTION AS A RESULT OF } \\
\text { BUSINESS INTELLIGENCE ADOPTION. }\end{array}$ & 0.824 & 0.646 & 0.959 & & \\
\hline & $\begin{array}{l}\text { THERE HAD BEEN AN IMPROVED EMPLOYEE RETENTION RATE IN OUR INSTITUTION BECAUSE } \\
\text { OF BUSINESS INTELLIGENCE ADOPTION. }\end{array}$ & 0.820 & & & & \\
\hline & $\begin{array}{l}\text { THERE HAD BEEN AN ENHANCED PRODUCTIVITY PER EMPLOYEE AS A RESULT OF BUSINESS } \\
\text { INTELLIGENCE ADOPTION. }\end{array}$ & 0.756 & & & & \\
\hline & $\begin{array}{l}\text { THERE HAD BEEN A SHORTENING OF WORK PROCESSES AND TASK HANDLING TIME } \\
\text { ATTRIBUTABLE TO BUSINESS INTELLIGENCE ADOPTION. }\end{array}$ & 0.574 & & & & \\
\hline & $\begin{array}{l}\text { THERE WAS A REDUCTION IN THE COST OF EFFECTIVE DECISION-MAKING ATTRIBUTABLE TO } \\
\text { BUSINESS INTELLIGENCE ADOPTION. }\end{array}$ & 0.618 & & & & \\
\hline & $\begin{array}{l}\text { THERE HAD BEEN A REDUCTION IN OUR OPERATIONAL COST AS A RESULT OF BUSINESS } \\
\text { INTELLIGENCE ADOPTION. }\end{array}$ & 0.678 & & & & \\
\hline & $\begin{array}{l}\text { THERE HAD BEEN AN ENHANCEMENT IN CUSTOMER SATISFACTION IN OUR INSTITUTION } \\
\text { ATTRIBUTABLE TO BUSINESS INTELLIGENCE ADOPTION. }\end{array}$ & 0.806 & & & & \\
\hline & $\begin{array}{l}\text { THERE HAD BEEN AN ENHANCEMENT OF THE INSTITUTION'S IMAGE AND BRANDING } \\
\text { ATTRIBUTABLE TO BUSINESS INTELLIGENCE ADOPTION. }\end{array}$ & 0.835 & & & & \\
\hline & $\begin{array}{l}\text { THERE HAD BEEN REDUCED MARKETING COSTS ATTRIBUTABLE TO BUSINESS INTELLIGENCE } \\
\text { ADOPTION }\end{array}$ & 0.849 & & & & \\
\hline
\end{tabular}


INTERNATIONAL JOURNAL OF ACADEMIC RESEARCH IN BUSINESS AND SOCIAL SCIENCES

Vol. 11, No. 1, 2021, E-ISSN: 2222-6990 @ 2021 HRMARS

\begin{tabular}{|c|c|c|c|c|c|c|}
\hline CONSTRUCTS & ITEMS & LOADING & AVEA & CR & $\mathbf{Q}^{2}$ & $\mathbf{R}^{2}$ \\
\hline & $\begin{array}{l}\text { THERE HAD BEEN A CORPORATE COST REDUCTION ATTRIBUTABLE TO BUSINESS INTELLIGENCE } \\
\text { ADOPTION. }\end{array}$ & 0.850 & & & & \\
\hline & $\begin{array}{l}\text { THERE HAD BEEN AN INCREASED REVENUE ATTRIBUTABLE TO BUSINESS INTELLIGENCE } \\
\text { ADOPTION. }\end{array}$ & 0.899 & & & & \\
\hline & $\begin{array}{l}\text { THERE HAD BEEN AN INCREASE IN RETURN ON INVESTMENT (ROI) ATTRIBUTABLE TO } \\
\text { BUSINESS INTELLIGENCE ADOPTION. }\end{array}$ & 0.932 & & & & \\
\hline & $\begin{array}{l}\text { THERE HAD BEEN AN IMPROVED COMPETITIVE ADVANTAGE ATTRIBUTABLE TO BUSINESS } \\
\text { INTELLIGENCE ADOPTION. }\end{array}$ & 0.917 & & & & \\
\hline
\end{tabular}

AVE $=$ ?LOADINGS $)+($ SUMMATION OF THE ERROR VARIANCES $)\}$ CR $=(?$ 


\section{Discriminant Validity}

Table 9 indicates that all constructs exhibited satisfactory discriminant validity, where the square root of AVE (diagonal) was larger than the correlations (off-diagonal) for all reflective constructs. In other words, indicators should load more strongly on their constructs rather than on other constructs in the research model, and the average variance shared between each construct and its measure should be higher than the variance shared between the construct and other constructs (Hair et al., 2017).

The HTMT criterion developed by Henseler et al. (2015) was used to assess the discriminant validity.

Table 9 illustrates that the criterion of the HTMT.90 and the HTMT.85 was fulfilled by all values. The discriminant validity is determined from an analysis of the results.

Table 9: Fornell-Larcker Criterion

\begin{tabular}{|c|c|c|}
\hline & BI ADOPTION & ORganizational PERfoRmance \\
\hline BI ADOPTION & 0.780 & \\
\hline ORganizational PERFORMANCE & -0.330 & 0.804 \\
\hline
\end{tabular}

\section{Structural Model Assessment}

Based on the evaluation shown in Table 10, the hypothesis relationship has a t-value $>2.33$ which is significant at 0.01 level of significance.

Table 10: Hypothesis Testing

\begin{tabular}{|c|c|c|c|c|c|c|}
\hline HYPOTHESIS & RELATIONSHIP & $\begin{array}{l}\text { PATH } \\
\text { COEFFICIENT }\end{array}$ & StD ERROR & T-VALUE & P-VALUE & DECISION \\
\hline $\mathrm{H} 1$ & $\mathrm{BIA} \rightarrow \mathrm{OP}$ & -0.308 & 0.073 & 4.205 & 0.000 & SUPPORTEL \\
\hline
\end{tabular}

Note 1: *T-Value $>1.65$, P-VAlue $<0.05 ; * *$ T-Value $>2.33$, P-VAlUe $<0.01$.

\section{Findings}

\section{Business Intelligence Adoption among Higher Education Institutions in Malaysia}

Data analysis found that none of the participating HEls is at the highest level of $\mathrm{BI}$ adoption, which was the innovate stage. A study by Owusu et al. (2017) found that most private universities in Malaysia are currently involved in level 2 of $\mathrm{BI}$ adoption.

Only 6.17 per cent of the participating HEls are at the lowest level of $\mathrm{BI}$ adoption, which is the operate stage. This is then followed by the optimize stage (19.14 per cent), which is the fourth level of $\mathrm{BI}$ adoption. Most of the participating HEls are at the integrate stage (37.65 per cent), which is the second level of $\mathrm{BI}$ adoption and the consolidate stage (37.04 per cent), which is the third level of $\mathrm{BI}$ adoption. Due to the large numbers of HEls categorized in the second and third level of $\mathrm{BI}$ adoption, HEls in Malaysia are at a moderate level of $\mathrm{BI}$ adoption. The operate stage is the starting point in the $\mathrm{BI}$ adoption journey because $\mathrm{BI}$ adoption among HEls in this level is not complex and is not resource-intensive. More resources will be necessary for HEls to proceed to the consolidate and integrate stages that emphasize more on analytical processes. These stages require HEls to overhaul their technology infrastructures, create a culture of sharing, improving the institution's human talents and fine-tuning knowledge processes. However, as such resources are not available to HEls in Malaysia, only a small 
number of HEls were categorized as being at the upper levels of $\mathrm{BI}$ adoption, which is the optimize stage. Based on these findings, there are opportunities to increase $\mathrm{BI}$ adoption in Malaysia's HEls to greater levels. HEls administrations wishing to encourage $\mathrm{BI}$ adoption needs to consider factors which significantly influence $\mathrm{BI}$ adoption among HEls in Malaysia.

\section{Outcome of BI Adoption}

The hypothesis has suggested that BI adoption will be significantly related to organizational performance. However, from the result of the tested hypothesis, it showed that BI adoption $(\beta=-0.304, p<0.05)$ has influenced the organizational performance. Therefore, the hypothesis is accepted based on the collected data.

The results of the analysis show that organizational performance of HEls is significantly impacted by $\mathrm{BI}$ adoption. The finding indicates that $\mathrm{BI}$ adoption among HEls helps in value creation for students, monitoring of how HEls deliver service and highlights opportunities for removing operating inefficiencies. Kaplan and Norton (1996) noted that through continuous improvement attributed to $\mathrm{BI}$ adoption, the $\mathrm{HEls}$ can determine the processes and competencies which are most critical and specify measures, including cycle time, quality, employee skills, and productivity to track them. These can lead to HEI managements improving the focus of their priorities for different business areas.

\section{Implication of the Study}

The implications of this study are:

Firstly, the findings in this study can guide the HEI administrations, especially those who are trying adopt $\mathrm{BI}$ in their operations. Since the findings point to moderate levels of $\mathrm{BI}$ adoption among HEls in Malaysia, there are still opportunities for increasing $\mathrm{BI}$ adoption levels among $\mathrm{HEls}$ to a higher level. To encourage higher BI adoption levels, there needs to be an emphasis on $\mathrm{HEl}$ administrators being aware of and understanding the advantages of $\mathrm{BI}$ adoption. $\mathrm{HEIS}$ can create policies to boost $\mathrm{BI}$ adoption and attain a higher rate of $\mathrm{BI}$ adoption by initiating awareness campaigns to convince all associated departments of the presumed prospective benefit of $\mathrm{BI}$ adoption.

Secondly, in using this study, future results could act as a starting point for the government and $\mathrm{BI}$ providers to determine the current state of $\mathrm{BI}$ adoption among HEls. They can create strategies and customize offerings that are better adapted for the needs of HEls by categorizing these institutions as a separate group. This would hopefully accelerate $\mathrm{BI}$ acceptance among HEls. Government and BI providers will then be equipped with the necessary knowledge to guide their policies and allocate resources more effectively to address challenges surrounding $\mathrm{BI}$ adoption among $\mathrm{HEls}$. From the perspective of $\mathrm{BI}$ providers, they can provide test intervals to HEls so that HEls can try the BI systems before completely accepting adopting them. Implementing trials of $\mathrm{BI}$ would grow understanding and show the advantages of sophisticated BI for HEls. Additionally, it can allow the BI provider to better assist the HEls in selecting the appropriate BI models that reflect the HEls needs.

Thirdly, from the view of the HEl, the essential effect of Bl's compatibility demonstrates that change management for $\mathrm{BI}$ adoption is a vital issue to be resolved before $\mathrm{BI}$ procurement. Thus, a consistency assessment before embracing $\mathrm{BI}$ is probable to be a great concept. Thus, the problem of resistance to modify can be monitored and reduced to the lowest effect. Only when issues and problems can be minimized then $\mathrm{BI}$ adoption would generate the presumed maximum advantage. Otherwise, if more time is required to tackle issues, the goal of deploying new IT innovations may be defeated. The decision to start and offer up BI adoption should be dependent on a thorough cost-benefit analysis. 
Fourthly, this study indicates that $\mathrm{BI}$ adoption could affect organization performance from both the financial and the non-financial aspects. The results showed that $\mathrm{HEI}$ administrators should holistically assess the benefits of $\mathrm{BI}$ adoption that are both tangible and intangible It is suggested that the benefit of having greater control of finances could encourage HEls to adopt $\mathrm{BI}$ in their operations.

\section{Conclusion}

In the last two decades, $\mathrm{BI}$ has become an increasingly essential component of the organizational decision-making process. BI adoption has reached a mature phase in large organizations, while HEls are still slow in $\mathrm{BI}$ adoption. $\mathrm{Bl}$ adoption is expected to assist organizations in attaining competitive advantages and improving organizational performance by turning operational data gathered into assets that drive strategic decisions.

Given these findings, researchers, government bodies, and IT service providers should recognize the potential of $\mathrm{BI}$ as a tool and emphasize the need for $\mathrm{Bl}$ adoption among HEls in Malaysia to boost organizational performance. Also, the researcher expects that the empirical findings in this research from the validated template will provide further knowledge of the benefits of $\mathrm{BI}$ adoption among HEls in Malaysia. The researcher also hopes that in the context of HEls, the model used in this study can be used to examine the impact of adopting other forms of technological innovations.

\section{Research Contributions}

The theoretical contribution of this study is adding the literature of technology innovation in order to enrich detailed knowledge and understanding the process of organizational IT adoption. It also contributes to the theory by evaluating the applicability of Resource-Based theory (RBT) that was developed and applied in developing countries such as Malaysia.

The practical contribution of this study, is an extending knowledge of analytical instruments in the enterprise to fill the knowledge gap in $\mathrm{BI}$ adoption and giving $\mathrm{HEI}$ administrators a stronger understanding that helps develop favourable attitudes towards $\mathrm{BI}$ adoption. $\mathrm{HEI}$ administrators will also be motivated to become more proactive in $\mathrm{BI}$ adoption to improve their likelihood of achievement in decision-making by enhancing productivity and increasing competitiveness.

\section{Acknowledgement}

This work was supported by the Universiti Sains Malaysia under Bridging Grant Scheme for the research (304/PPAMC/6316078).

\section{References}

Barney, J. (1991). Firm Resources and Sustained Competitive Advantage. Journal of Management, 17(1), 99-120. https://doi.org/10.1177/014920639101700108

Bhanu, F., \& Magiswary, D. (2010). Electronic Customer Relationship Management Systems (E-CRM): A knowledge management perspective. 2010 International Conference on Education and Management Technology, 409-413. https://doi.org/10.1109/ICEMT.2010.5657629

Boonsiritomachai, W., McGrath, G. M., \& Burgess, S. (2016). Exploring business intelligence and its depth of maturity in Thai SMEs. Cogent Business \& Management, 3(1), 1-17. https://doi.org/10.1080/23311975.2016.1220663

Cohen, J. (1988). Statistical power analysis for the behavioral sciences. Statistical Power 
Analysis for the Behavioral Sciences (Vol. 2nd). https://doi.org/10.1234/12345678

Davis, J., Miller, G. J., \& Russell, A. (2006). Information revolution : using the information evolution model to grow your business. SAS Institute Inc.

DELL. (2013). Academic Analytics Business Intelligence for Higher Education. Campus Technology.

Dresner Advisory Service. (2018). 2018 Wisdom of Crowd: Business Intelligence Market Study. EDUCASE. (2017). Higher Education IT Trend 2017.

Falk, R., \& Miller, N. B. (1992). A Primer for Soft Modeling. Open Journal of Business and Management, 2(April), 103.

Gartner. (2013). BI software market to grow 9\% in Malaysia. Gartner Press Release.

Gartner. (2016). Gartner Says Worldwide Business Intelligence and Analytics Market to Reach $\$ 18.3$ Billion in 2017. Retrieved November 19, 2017, from https://www.gartner.com/newsroom/id/3612617

Gartner. (2019). Gartner Says Self-Service Analytics and BI Users Will Produce More Analysis Than Data Scientists Will by 2019, pp. 2018-2020.

Gavrea, C., Ilies, L., \& Stegerean, R. (2011). Determinants of organizational performance: The case of Romania. Management \& Marketing, 6(2), 285-300.

Georgopoulos, B. S., \& Tannenbaum, A. S. (1957). A Study of Organizational Effectiveness. American Sociological Review, 22(5), 534. https://doi.org/10.2307/2089477

Hair, J. F., Hult, G. T. M., Ringle, C. M., \& Sarstedt, M. (2017). A Primer on Partial Least Squares Structural Equation Modeling (PLS-SEM). Long Range Planning (Second). SAGE Publications Inc. https://doi.org/10.1016/j.Irp.2013.01.002

Hatta, N. N. M., Miskon, S., \& Abdullah, N. S. (2017). Business Intelligence System Adoption Model for SMEs. In Pacific Asia Conference on Information Systems (PACIS) 2017 Proceedings.

Henseler, J., Ringle, C. M., \& Sarstedt, M. (2015). A new criterion for assessing discriminant validity in variance-based structural equation modeling. Journal of the Academy of Marketing Science, 43(1), 115-135. https://doi.org/10.1007/s11747-014-0403-8

Kaplan, R. S., \& Norton, D. P. (1996). The Balanced Scorecard: Translating Strategy In Action. Harvard Business School Press. Boston, MA. https://doi.org/10.1109/JPROC.1997.628729

Lebas, M., \& Euske, K. (2007). A conceptual and operational delineation of performance. In Business Performance Measurement: Unifying Theories and Integrating Practice, Second Edition (pp. 125-140). https://doi.org/10.1017/СВ09780511805097.008

Mahoney, J. T., \& Pandian, J. R. (1992). The Resource-Based View within the Conversation of Strategic Management. Strategic Management Journal, 13(5), 363-380. https://doi.org/10.2307/2486455

Malaysian Ministry of Education. (2015b). Malaysia Education Blueprint 2015-2025 (Higher Education). Malaysian Ministry of Education (Vol. 2025). https://doi.org/10.5923/j.ijis.20120206.05

Olszak, C. M. (2016). Toward Better Understanding and Use of Business Intelligence in Organizations. Information Systems Management, 33(2), 105-123. https://doi.org/10.1080/10580530.2016.1155946

Owusu, A., Ghanbari-Baghestan, A., \& Kalantari, A. (2017). Investigating the Factors Affecting Business Intelligence Systems Adoption: A Case Study of Private Universities in Malaysia. International Journal of Technology Diffusion, 8(2), 1-25. https://doi.org/http://dx.doi.org/10.4018/IJTD.2017040101 
Ong, V. K. (2016). Business Intelligence and Big Data Analytics for Higher Education: Cases from UK Higher Education Institutions. Information Engineering Express, 2(1), 65-75. https://doi.org/10.1109/IIAI-AAI.2015.178

PricewaterhouseCoopers. (2017). HE Matters: Managing Risk. Retrieved October 13, 2019, from https://www.ihgplc.com/files/reports/ar2008/index.asp?pageid=32

Rahmat, A., Ahmad, A., \& Ta'a, A. (2016). Business Intelligence Readiness for Higher Learning Institution (IHL): Preliminary Study and Research Model. British Journal of Applied Science \& Technology, 15(5), 1-10. https://doi.org/10.9734/BJAST/2016/24383

Rezaie, K., Ansarinejad, A., Haeri, A., \& Nazari-Shirkouhi, A. (2011). Evaluating the business intelligence systems performance criteria using group fuzzy AHP approach. In Proceedings - 2011 UKSim 13th International Conference on Modelling and Simulation, UKSim 2011. https://doi.org/10.1109/UKSIM.2011.75

Sacu, C., \& Spruit, M. (2010). BIDM - The business intelligence development model. ICEIS 2010 - Proceedings of the 12th International Conference on Enterprise Information Systems, 1 DISI, 288-293.

Seashore, S. E., \& Yuchtman, E. (1967). Factorial Analysis of Organizational Performance. Administrative Science Quarterly, 12(3), 377-395. https://doi.org/10.2307/2391311

Wieder, B., \& Ossimitz, M. L. (2015). The Impact of Business Intelligence on the Quality of Decision Making - A Mediation Model. Procedia Computer Science, 64, 1163-1171. https://doi.org/10.1016/j.procs.2015.08.599

Wong, B. T. M., Li, K. C., \& Choi, S. P. M. (2018). Trends in learning analytics practices: a review of higher education institutions. Interactive Technology and Smart Education, 15(2), 132-154. https://doi.org/10.1108/ITSE-12-2017-0065 